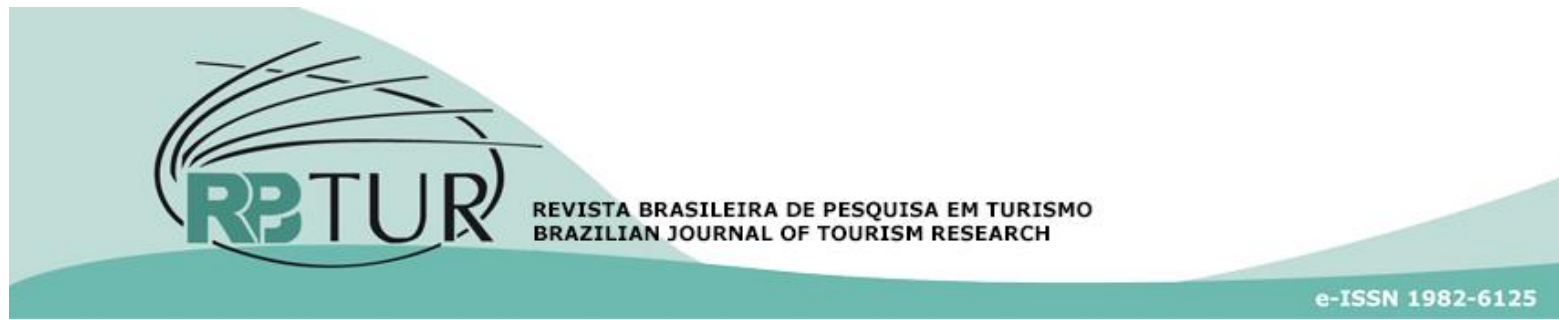

\title{
Papers
}

\section{Migrant entrepreneurship, value-creation practices and urban transformation in São Paulo, Brazil}

\section{Empreendedorismo de migrantes, práticas de criação de valor e transformação urbana em São Paulo, Brasil \\ Iniciativas empresariales de migrantes, prácticas de creación de valor y transformación urbana en São Paulo, Brasil}

\author{
Peter Lugosi ${ }^{1}$; Thiago Allis ${ }^{2}$ \\ ${ }^{1}$ Oxford Brookes University, Oxford, United Kingdom. \\ 2 University of São Paulo, São Paulo, SP, Brazil.
}

\begin{tabular}{|c|c|}
\hline & Abstract \\
\hline $\begin{array}{l}\text { Keywords: } \\
\text { Entrepreneurship. } \\
\text { Gastronomy. } \\
\text { Hospitality. } \\
\text { Migration. } \\
\text { Urban tourism. }\end{array}$ & $\begin{array}{l}\text { This paper examines the entrepreneurial practices of migrants, including refugees, establishing } \\
\text { and operating businesses providing food, hospitality, leisure, tourism and events-related ser } \\
\text { vices and experiences. Drawing on empirical data gathered in São Paulo, Brazil, the study con } \\
\text { ceptualises how migrants create cultural 'goods' (encompassing material objects, services and } \\
\text { experiences), which have been subjected to valuation processes. The paper considers the prac } \\
\text { tices through which migrants mobilise identities, histories, and culturally-specific knowledge as } \\
\text { resources in constructing experiential propositions. Moreover, we distinguish between five sets } \\
\text { of practices: objectification of self; aestheticisation of otherness; authentication of place-spe } \\
\text { cific food experiences; constructing hospitality venues as cultural spaces; and vitrine-ing (cre } \\
\text { ating platforms for showcasing migrant talent). We discuss the potential consequences of these } \\
\text { practices for migrants, consumers, urban environments and their residents, and identify ave } \\
\text { nues for future research. }\end{array}$ \\
\hline
\end{tabular}

Resumo

\section{Palavras-chave:}

Empreendedorismo. Gastronomia. Hospitalidade. Migração.

Turismo urbano.
Este artigo analisa práticas de empreendedorismo de migrantes, incluindo refugiados, que são proprietários ou administram negócios vinculados à prestação de serviços e experiências de alimentacão, hospitalidade, lazer, turismo e eventos. Baseado em dados empíricos coletados em São Paulo (Brasil), o estudo, do ponto de vista conceitual, aborda as formas através das quais imigrantes criam "bens" culturais (englobando objetos materiais, serviços e experiências), que foram submetidos a processos de valoração. 0 artigo considera as práticas através das quais migrantes mobilizam identidades, histórias, e conhecimentos culturais específicos como recursos para a construção experiências. Ademais, diferenciamos cinco conjuntos de práticas: a objetificação do eu, a estetização da alteridade, autenticação de experiências gastronômicas em locais específicos, construção de locais de hospitalidade como espaços culturais e práticas de "vitrinização" (criando plataformas para a divulgação de talentos dos migrantes). Discutimos potenciais consequências dessas práticas para migrantes, consumidores, ambientes urbanos e seus residentes, e identificamos caminhos para pesquisas futuras.

Resumen

Este artículo analiza iniciativas empresariales de migrantes, refugiados incluídos, que son propietarios o gestores de negocios vinculados a la oferta de servicios y experiencias de alimenta- 


\section{Palabras clave:}

Espíritu empresarial.

Gastronomía.

Hospitalidade.

Migración.

Turismo urbano. ción, hospitalidad, ocio, turismo y eventos. A partir de recolección de datos en São Paulo (Brasil), el estudio, desde el punto de vista conceptual, aborda las formas a través de las cuales migrantes crean "bienes" culturales (englobando objetos materiales, servicios y experiencias), que fueron sometidos a procesos de valoración. Además, se diferencian cinco conjuntos de prácticas: la objetificaación del yo, la estetización de la alteridad, autenticación de experiencias gastronómicas en lugares específicos, construcción de locales de hospitalidad como espacios culturales y prácticas de vitrinización (creando plataformas para la promoción de talentos de los migrantes). Discutimos posibles consecuencias de estas prácticas para migrantes, consumidores, entornos urbanos y sus residentes, e identificamos caminos para futuras investigaciones.
Reviewed by pairs.

Received in: 13/10/2018.

Accepted in: 08/12/2018.
How to cite: Lugosi, P. ; Allis, T. (2019). Migrant entrepreneurship, value-creation practices and urban transformation in São Paulo, Brazil. Revista Brasileira de Pesquisa em Turismo, São Paulo, 13 (1), p. 141-163, jan./abr. http://dx.doi.org/10.7784/rbtur.v13i1.1538

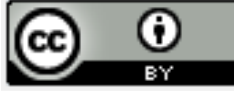

\section{INTRODUCTION}

Emerging literature on tourism, migration and other forms of 'lifestyle mobilities' points to the proliferation and normalisation of movement (Büscher \& Urry, 2009; Cohen, Duncan, \& Thulenmark, 2015; Germann Molz \& Gibson, 2007). Within this 'new mobilities' discourse, movement (of people, capital, goods, services, images and ideas), its representation and embodied experiences become central areas of focus in analysis of contemporary societies (cf. Creswell, 2010; Sheller \& Urry, 2006; Urry, 2007). Examining these interconnected issues raises important questions regarding who or what moves, how, on what basis, and the different consequences of these mobilities. Mobility is shaped by issues of class, gender, ethnicity, religion, age, access to capital, nationality etc. (Creswell, 2010). Furthermore, desired and privileged forms of mobility, in tourism or lifestyle migration for example, may be seen as interlinked and positive for multiple stakeholders involved; but other forms of movement, driven by economic displacement or conflict for instance, involves fundamentally different experiences, risks and consequences.

Crisis-driven migration (including by human-made and natural disasters) has grown since the mid-20th century and intensified over the past decade. Between 2013 and 2018, the number of displaced people has increased $34 \%$ to 68.5 million (UNCHR, 2018). It is interesting to note that tourism arrivals have also grown by $18 \%$ during this period (World Bank, 2018). In many cases, privileged and 'desirable' types of movement, such as tourism, coexist with forced and therefore 'undesirable' ones, which are perceived to impact negatively on the interests of states, their citizens and commercial organisations in the tourism and hospitality sector (Ivanov \& Stavrinoudis, 2018). However, rather than focusing on negative consequences of forced human movement on tourism, this paper examines alternative, constructive intersections of tourism, hospitality and migration, including among refugees whose movement was driven by crisis.

Migration, hospitality and tourism are interlinked in multiple ways (Hall \& Williams, 2002). Migrants often form a large part of the tourism workforce, and thus contribute to the service experiences envisioned by organisations and destinations (cf. Baum, Kralj, Robinson, \& Solnet, 2016; Duncan, Scott, \& Baum, 2013; Joppe, 2012). Migration also drives diverse forms of travel including visiting friends and relatives (VFR), retirement and ancestral tourism (cf. Dwyer, Seetaram, Forsyth, \& King, 2014; Hall \& Williams, 2002; Janta, Cohen, \& Williams, 2015; O'Reilly, 2003; Williams, King, Warnes, \& Patterson, 2000). Indeed, as more places receive migrants and refugees, interactions between practices, materialities and experiences of migration and those of hospitality and tourism intensify.

This paper extends existing knowledge on the intersections of hospitality, tourism and migration by exploring how migrants (including refugees and economic migrants) engage in valuation practices that transform people, knowledge, cultural capacities and material objects into circulating assets. Focusing on migrants involved in the creation and operation of five hospitality venues in São Paulo, Brazil: Al Janiah, Biyou'Z, Congolinária/Fatiado Discos, Majâz and Open Taste/House of Food, we explore how value is created, qualified and 
mobilised. More specifically, we distinguish between five different areas of practice: objectification of self; aestheticisation of otherness; authentication of place-specific food experiences; constructing hospitality venues as cultural spaces; and vitrine-ing i.e. creating platforms for showcasing migrant talent. In doing so, we foreground how different ascriptions and adoption of contemporary migrant identities on or by different individuals are part of value creation processes, including potential interplays with urban change and urban tourism.

Drawing on insights from valuation studies (Baka, 2015; Ren \& Mahadevan, 2018; Ren, Petersen, \& Dredge, 2015) we consider different forms of agency exercised by migrant entrepreneurs. We argue that these actors engage in various strategies of value creation by mobilising and circulating, in different dimensions, aspects of migrants' histories, identities, cultural knowledge and objects, particularly associated with food and its commercial provision. This involves practices of objectification and transformation, representing various forms of commodification. As a preliminary effort, we evaluate the processes and implications of these practices, which, we argue, can be interpreted as forms of creative entrepreneurship and empowerment, but also as potential acts of exploitation. The paper discusses the implications of these practices for migrants, host societies and places, and it identifies avenues for future research.

\section{VALUATION PRACTICES}

The concept of valuation including its application in tourism is well documented and the intention is not to provide a detailed review or critique here (cf. Kjellberg et al., 2015; Ren \& Mahadevan, 2018; Ren et al., 2015). In short, valuation refers to the practices through which the worth of tradable 'goods', which encompasses material goods, experiences and services, is decided. Following Callon (2007), goods are produced, qualified, traded and consumed alongside and through supporting services; experiences involve goods and services; therefore, the distinction between them is blurred (Callon et al., 2002; Lugosi, 2016).

The value of goods are negotiated and re-established as producers, intermediaries and consumers evaluate market conditions, consumer desires and needs, the qualities of goods, alongside other goods, and the ability of goods to address specific needs (Cochoy, 2004, 2008). Valuation requires that, 'the entities taken into account have to be detached...moved, arranged and ordered in a single space'; ... they 'are associated with one another and subjected to manipulations and transformations' and 'a result has to be extracted' (Callon \& Muniesa, 2005: 1231). Goods are 'objectified' and 'singularized', wherein their qualities are defined, making them valuable to intermediaries and consumers (Callon \& Muniesa, 2005).

Singularized goods are positioned in the market place by producers attempting to construct propositions regarding their benefits; whilst consumers evaluate these propositions, attributes and their value in relation to their needs, values and desires. Valuation and thus value-creation is co-created, requiring shared frames of reference and agreed indexes, through which the worth of goods are qualified (Callon, 1998; Callon et al., 2002; Cochoy, 2004, 2008). Within this paper, we examine how migrants exercise their agency, through their engagement with other market actors, including cultural intermediaries and consumers, to construct and negotiate the value of foods, cultures, artefacts, identities, and hospitality and tourism experiences in a cultural marketplace. This allows us to explore the potential consequences of valuation practices on migrants, consumers, residents and the urban locations in which they co-exist.

\section{STUDY CONTEXT AND METHODS}

\subsection{Migration in Brazil}

Brazil has a long history of migration: similarly to the US, Argentina and Mexico, it received several substantial waves of migrants since the mid-19 ${ }^{\text {th }}$ century, driven in part by institutional agreements between Brazil and other countries, alongside economic necessity as people search for opportunities to create better lives through movement. Between 1894 and 1933, almost 4 million immigrants arrived in Brazil, mainly Italians, Portuguese, Spanish, Japanese, Syrians and Turkish. The 1950s was also a period of strong immigration with $30-80,000$ entrants per annum. From 1960, this flow reduced and stabilised at relatively low levels - less than 10,000 per annum (IBGE, 2000, p. 225-226). 
Since 2010, Brazil has received more than 100,000 immigrants annually. By the end of 2017, Brazil had 10,145 recognized refugees with another 86,000 applications under evaluation. In 2017, Venezuelans accounted for more than half of applications (about 17.000); in contrast to 2012, when there was only 1 request (Secretaria Nacional de Justiça, 2018). Importantly, a large proportion of refugees travel to São Paulo to settle and find work (Secretaria Nacional de Justiça, 2018). The history of migration and intercultural mixing, coupled with the dramatic rise of refugees, makes Brazil, and São Paulo in particular, an important empirical context for exploring migrants' experiences and their entrepreneurial value-creation practices.

\subsection{Data collection procedures and sampling}

The data underpinning this paper were generated as part of a collection of studies examining intersections between migration, organisations and labour market integration. This body of research focused on refugees' and other migrants' engagement with formal and informal organisations and networks, examining how these interactions shaped their entry into and transition through the labour market, their subsequent mobility, as well as their settlement. The research was developed in the constructivist tradition, using an inductive approach in its collection and analysis of data gathered in the United Kingdom and Brazil (Lincoln \& Guba, 2013; Allis \& Lopez, 2018). However, the current paper is based primarily on qualitative data collected in São Paulo, Brazil.

Similar to analogous research, the wider study used composite data gathered through online and offline observation and in-situ dialogue (cf. Smith, Egedy, Csizmady, Jancsik, Olt, \& Michalkó, 2018; Torres, Lugosi, Orlowski, \& Ronzoni, 2018). A summary of the procedures, including their scope and focus is summarised in Table 1. Primary data gathering was complemented by three interactive workshops with stakeholders undertaken in São Paulo in September 2018, including researchers, service providers, organisational operators and activists. The workshops had three substantial functions: first, they encouraged us to reflect on the issues identified through data collection and initial cycles of analysis; second, they forced us to order and display our findings to external audiences, acting as another analytical filtering process; and third, in presenting our emerging findings, interactions with our audiences provided alternative perspectives on the organisations engaging migrants and refugees, and their experiences.

\begin{tabular}{|c|c|c|}
\hline Data collection method & Procedures & Scope and focus \\
\hline $\begin{array}{l}\text { Offline non/semi-par- } \\
\text { ticipant observation }\end{array}$ & $\begin{array}{l}\text { Visits by two researchers to } 11 \text { purposively } \\
\text { selected social businesses, charities and } \\
\text { hospitality-related venues (alongside infor- } \\
\text { mal visits to numerous other hospitality and } \\
\text { retail businesses, charitable organisations } \\
\text { and cultural centres in various city districts); } \\
\text { Engaging in digitally recorded and non-rec- } \\
\text { orded in-situ conversations with } 18 \text { owners } \\
\text { and operators; } \\
\text { Collection of photographic evidence of } \\
\text { venue layout, design, objects, and staff; } \\
\text { Making informal interpretative field notes in } \\
\text { notebook and mobile phone }\end{array}$ & $\begin{array}{l}\text { Identifying and critically reviewing organi- } \\
\text { sational procedures and venues' experi- } \\
\text { ential propositions; } \\
\text { Evaluating the use of materiality, includ- } \\
\text { ing objects, decorations, uniforms, food } \\
\text { and drinks; } \\
\text { Evaluating representational practices, in- } \\
\text { cluding menus, in-venue promotional ma- } \\
\text { terial and verbal descriptions of food, } \\
\text { drink and procedures; } \\
\text { Exploring histories, motivations and ex- } \\
\text { periences of owners and operators; } \\
\text { Exploring owner/operator perspectives } \\
\text { on the practices of related stakeholders, } \\
\text { including migrants, other owners/ opera- } \\
\text { tors, clients/consumers, governmental } \\
\text { and non-governmental agents }\end{array}$ \\
\hline $\begin{array}{l}\text { Online non-participant } \\
\text { observation }\end{array}$ & $\begin{array}{l}\text { Visits to venues' and organisations' home } \\
\text { and social media pages; } \\
\text { Using venue/organisation and owner names } \\
\text { in Internet search engines to identify online } \\
\text { representations; } \\
\text { Downloading, reading and interpreting rep- } \\
\text { resentational practices }\end{array}$ & $\begin{array}{l}\text { Evaluating representations of organisa- } \\
\text { tions, venues, their operators and clients, } \\
\text { including self- representations and those } \\
\text { of consumers and cultural commentators }\end{array}$ \\
\hline
\end{tabular}

The study adopted a multi-step, purposive approach to sampling organisations, venues, stakeholders and online platforms (Patton, 2015). The essential inclusion criteria for selecting organisations were their direct engagement with migrants either as owners, operators or clients/consumers. In the first step, relevant organisations and venues for site visits were identified from the second author's knowledge of São Paulo's 
migrant networks across a range of nationalities. In the second step, pre-visit contacts with owners and operators, and personal interactions during site visits, were used to identify appropriate individuals for further in-situ conversations. Selected participants were professionals with ongoing engagement with the organisations, who consequently had insiders' perspectives on their operations. Online representations were identified using the names of the venues or their owners/operators, and therefore also selected according to their relevance to the scope and focus of the study and the themes identified through ongoing data gathering and analysis.

Site visits were made to 11 social businesses, charities and commercial enterprises; however, the focus in this paper is on data related specifically to food, hospitality and tourism venues and their operators. Visits involved largely non-participant observation (Adler \& Adler, 1989) and an open, exploratory approach to data sampling (Adler \& Adler, 1998). During visits, the researchers recorded visual evidence of venues and organisations, focusing in particular on three aspects: designs, users and practices. This was complemented by gathering other context-specific material e.g. flyers, posters and other documents. For commercial organisations, this included marketing and publicity material, for example regarding their food, hospitality and tourism-related experiential propositions.

Site visits provided opportunities for in-situ dialogue with 18 people including migrant entrepreneurs, individuals involved with NGOs, charities and social businesses, as well as researchers and activists based in São Paulo. These conversations examined their backgrounds, including their histories, activities and experiences, alongside the past and present practices of the organisations with which they were associated. A central focus of the study was identifying the challenges and opportunities faced by migrants, including refugees, in settlement and engagement with the labour market. However, during the data collection, migrants' entrepreneurial practices involving food, hospitality and tourism became substantial themes and thus explored further in the data collection and analysis.

The online dimension of the study considered textual and visual representations of hospitality and tourism venues, and their operators, available through popular media, including cultural commentaries and reviews in newspapers and lifestyle magazines, social media platforms and blogs (cf. Lugosi, Janta, \& Watson, 2012). This provided useful background information about the venues, the migrants and refugees who founded, owned and in many cases operated them, alongside their employees, the foods they served and consumers' perceptions of the venues.

The food, hospitality and leisure-related organisations discussed in this paper were mainly founded, owned or run by individuals born outside Brazil (please see appendix 1 for details of the venues and operators). However, one was co-founded by a second-generation migrant, and several were co-operated by Brazilianborn partners. The owners/operators had diverse backgrounds, and they experienced different forms of mobility. Furthermore, in many cases, the venues they managed also employed Brazilians, as well as migrants from other nations.

\subsection{Data analysis}

The study involved concurrent data gathering and analysis performed in multiple cycles, which allowed us to respond in-situ to new insights gained through site visits and interactions with owners, operators and users. Reflecting the analysis in similar 'unfolding' qualitative studies, themes were then discussed, evaluated and refined through an interactive process between the authors (cf. Purnell \& Breede, 2018; Davis \& Breede, 2015). The observational data were analysed during and immediately after each site visit, with the researchers reflecting through dialogue on individual observations and interpretations about the venues, including material and representational practices. These immediate analytical interpretations were used to enhance our field notes. Similarly, insights generated through in-situ dialogue were critically evaluated immediately after their conclusion in an initial analysis cycle. Again, evaluative reflections on these verbal interactions were used to enhance our field notes.

The issues identified through initial cycles of analysis drove us to conduct subsequent cycles of analysis and further data collection. Specifically, analysing online representations became a form of data triangulation providing alternative perspectives on the venues, organisations and their stakeholders. These additional 
data, collected and interpreted by the researchers independently, were also analysed interactively, through ongoing dialogue.

Subsequent cycles of analysis involved both researchers actively engaging with the different data, interpreting their significance through literature from mobilities, valuation and hospitality studies, to identify the form and conceptual scope of distinct and significant themes. Written interpretations of the conceptual themes were initially produced independently by the two researchers. These were subsequently reviewed by the other researcher, and then synthesised into a single document, which underwent numerous revisions following ongoing dialogue.

\section{FINDINGS AND DISCUSSION}

The following sections examine five sets of related practices through which value was created and mobilised. It is important to stress that not all of the practices identified here were evident in every venue, or emerged in the same way; nevertheless, the majority of the practices highlighted were not unique to a single venue.

\subsection{Objectification of self}

Previous work by practitioners and academics has recognised that the identities of restaurant operators and chefs are assets that can be mobilised to create distinctive organisational cultures, and to construct valued foodservice brands in cultural marketplaces (cf. Jones, 2009; Meyers, 2006). Svejenova, Mazza and Planellas (2007) theorised that entrepreneurial personalities in food and hospitality domains have the capacity to drive creativity and innovation; and, importantly, project their personalities and values through integrating resources and creating new publics for their 'goods'. Analogous capacities and practices were observed in this study: migrant entrepreneurs were central, firstly, in creating and operating the hospitality spaces; and secondly, in becoming part of venues' experiential propositions. For example, an entire wall in Biyou'Z was dedicated to press coverage and accolades of the restaurant and its owner (see Figure 1). These representational practices were purposive attempts to inextricably couple her personality with that of the venue, and to curate representations of the hybrid tourism entity or 'good'. Specifically, these practices of singularization tied the person to space and the experiences it proposed. Moreover, the focus on external recognition of (her) achievements and successes were arguably attempts to 'frame' the overall touristic good as distinct and 'valued' in the cultural marketplace.

Many restaurants use their owner's personalities, values and histories to differentiate and position their products in a marketplace. A key issue in our data is the purposive foregrounding of 'migration', 'migrants' and 'otherness' in these entrepreneurs' practices. The owner, as migrant, alongside the restaurant as experiential space for encountering novelty, and the foodstuffs as material carriers of otherness, were assembled as objectified, and therefore spectacular, consumption goods. 
Figure 1 - Displays of articles written about Biyou'Z and its owner

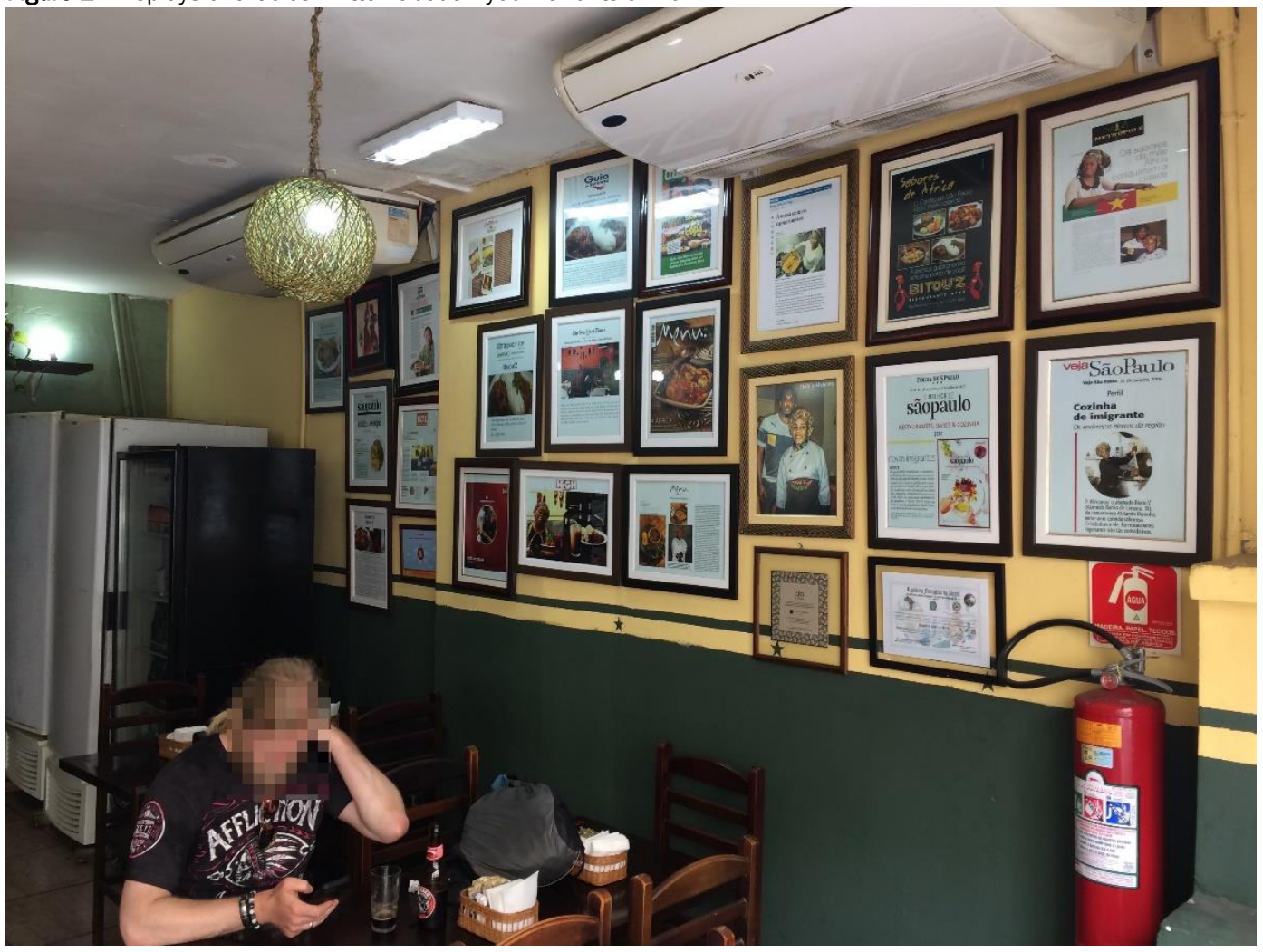

Figure 2 - View from inside Biyou'Z

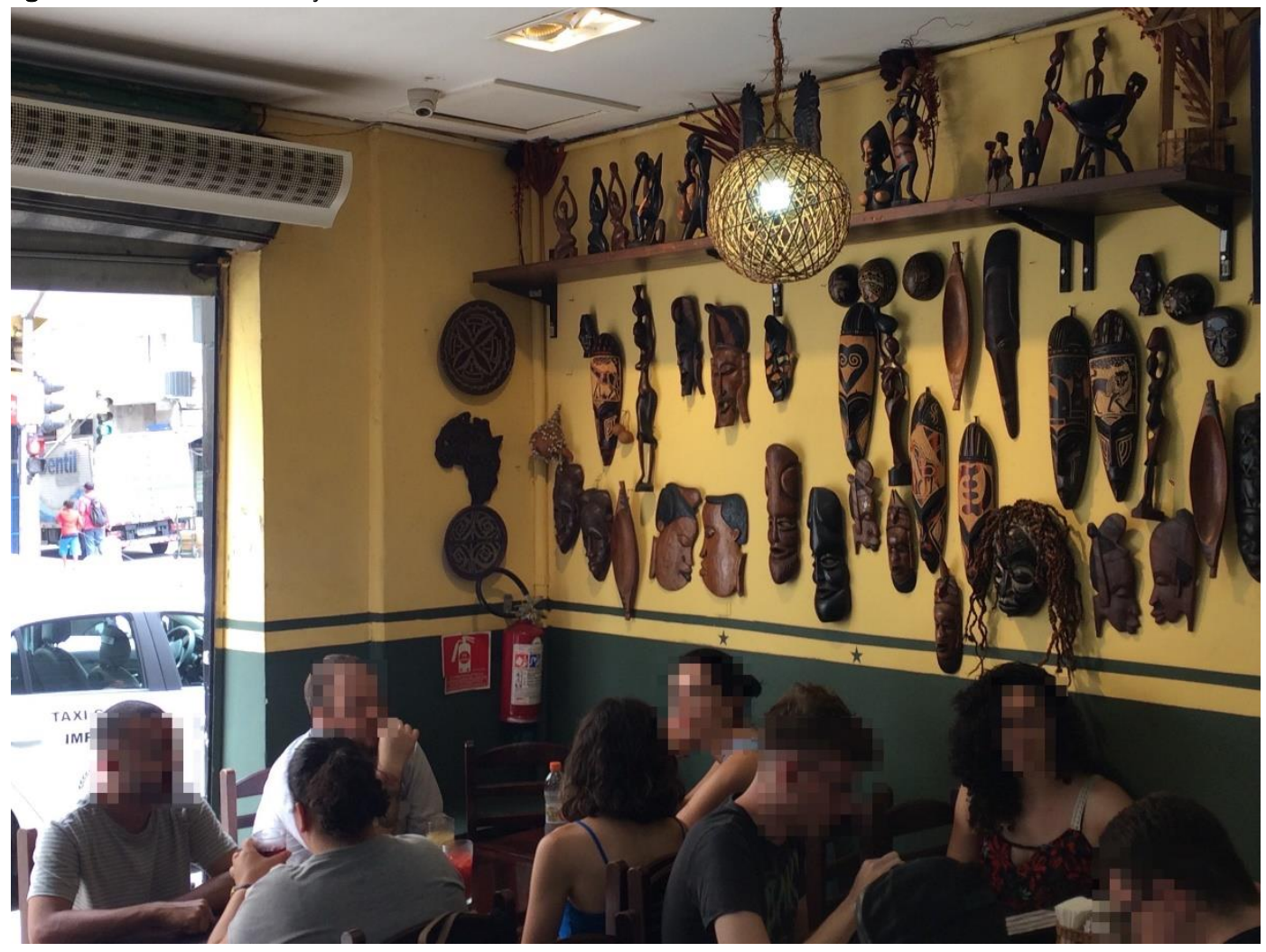


It is interesting to compare Biyou'Z's frontage (Figure 3), with that of the neighbouring African restaurant, Mercy Green (Figure 4), managed by a Cameroonese operator, which had no exterior sign showing the name of the venue, and was hidden from the street view by a plastic curtain. It had functional furnishings, a more modest food offering, and Senra (2014), a cultural commentator, suggested it targets non-Portuguese speaking Africans. In contrast, Biyou'Z's frontage and furnishings pointed to a strategy of display, which sought to make it a visible touristic or leisure attraction in an urban landscape - targeting local and non-local consumers (see Figure 3). As Hansen argued (2008), the personality and surrounding apparatus, in this case, the restaurant and its foodstuffs were assembled as consumable spectacles within a marketplace. Self and media representations, from consumers and cultural commentators were therefore essential to the market practices through which value was assigned to the objectified person, the space and to the experiences they offered in combination.

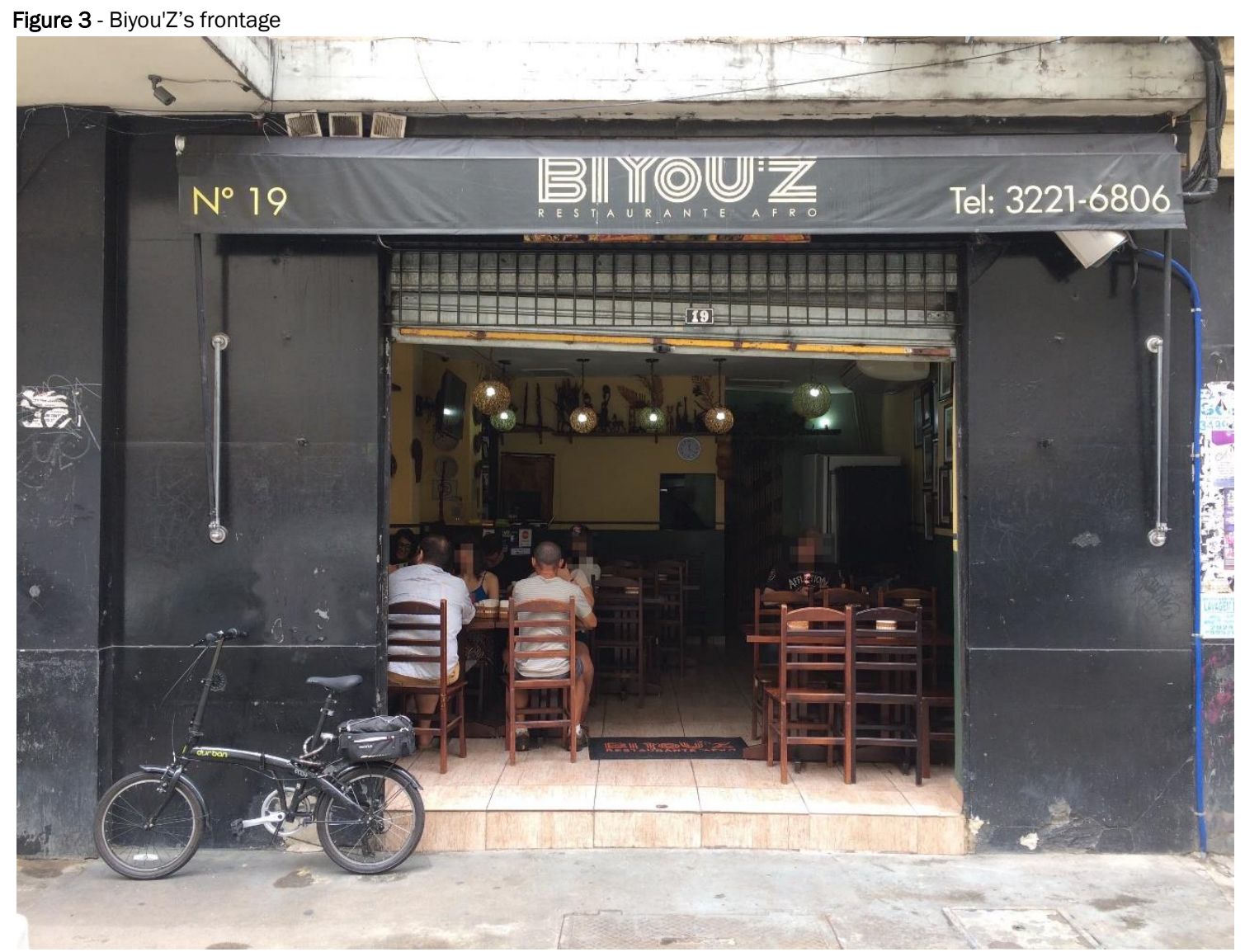

The other venues discussed in this paper did not necessarily place similar emphasis on this type of display, especially in-venue representation of the owners and journalistic coverage of their endeavours. However, operators of other venues maintained strong online presence, using social media platforms to present their personalities and life histories, and the unique features of their venues. Analogous trends have been identified in studies of social media-driven celebrity culture (cf. Marwick, 2013, 2015; Marwick \& boyd, 2011; Papacharissi, 2012): individuals' curated self-presentations became part of branding practices through which they mobilised aesthetic, cultural and social capital to ascribe value to themselves and the hospitality venues they created. Value-creation continued to personalise the experiential propositions of the physical venues, coupling subject (owner/operator) with object (hospitality space). 
Figure 4 - Biyou'Z's neighbour Mercy Green's frontage

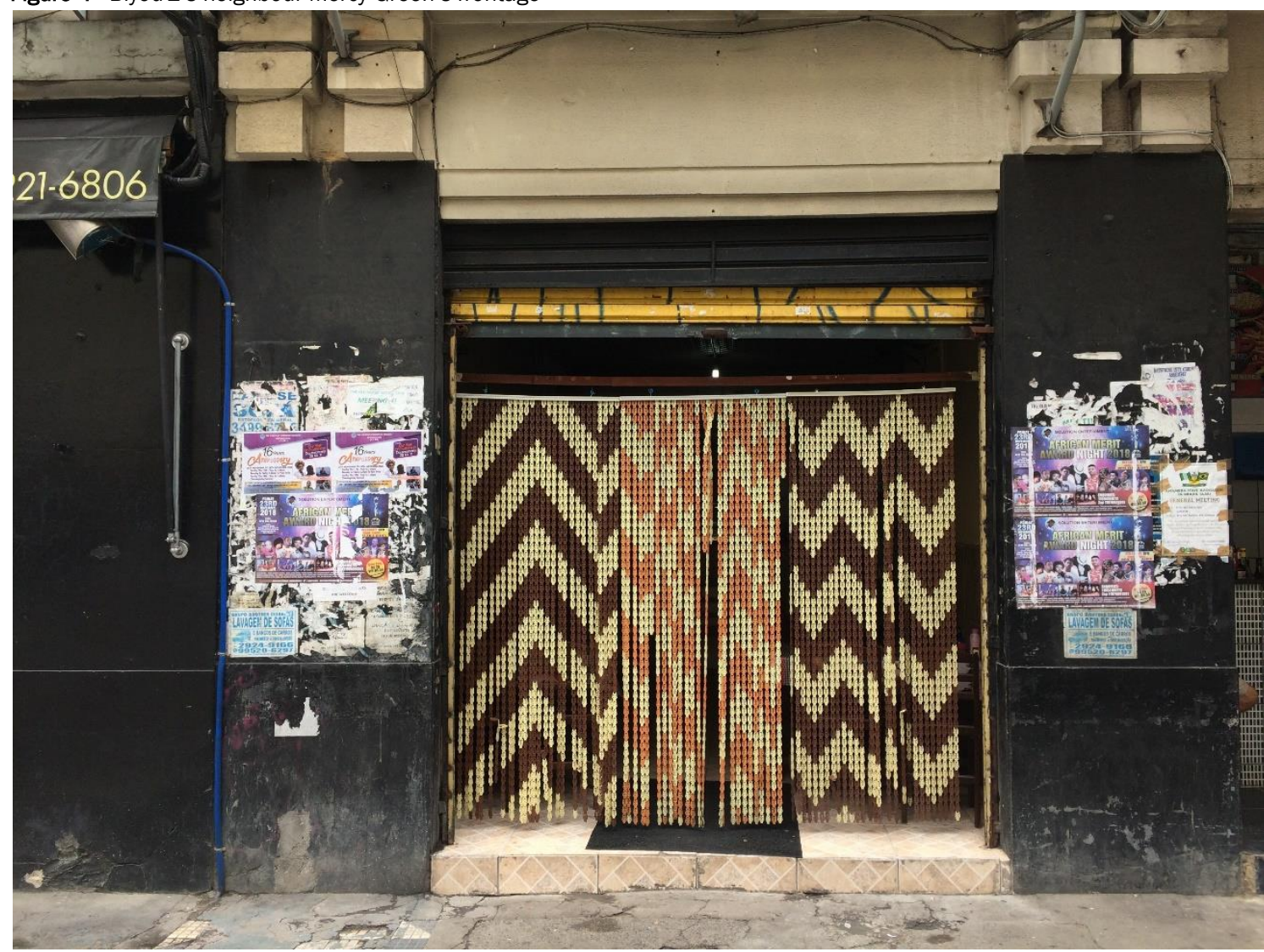

\subsection{Aestheticisation of 'otherness'}

Curated representations of self by the owners/operators link to a second set of practices evident in these venues: the aestheticisation of otherness. Migration and otherness were encoded through material-semiotic valuation strategies (Lury, 2012). Specifically, venues such as Al Janiah and Majâz used highly stylised, artistic representations of Arabic and Palestinian life and culture. More significantly, both venues drew on explicit and implicitly coded symbols, including artwork referencing broader political struggles of Palestinians and their relations with Israel (see Figure 5). In doing so, the valuation practices imbued hospitality space with multiple cultural and political meanings, thus broadening their experiential propositions with new cultural discourses. These representational acts coupled mundane acts of eating and drinking with political statements of affiliation (with Palestine and Palestinian refugees) and thus critiques of Israel and its policies.

However, it is important to note that aestheticisation practices emerged more widely in other venues. Stylised graffiti featured in Fatiado Discos (e.g. Figure 6, and Biyou'Z was decorated with African carvings; see Figure 2). These practices mirror similar stylisation of hospitality spaces identified in other international studies (cf. Lugosi, Bell, \& Lugosi, 2010). They can be interpreted as purposeful attempts to construct venue atmospherics as part of theming (cf. Berry, Wall, \& Carbone Brown, \& Patterson, 2000; Hoffman \& Turley, 2002). However, beyond simply creating stimuli effects among consumers, they can also been seen as broader strategies to mobilise various forms of cultural capital - thus distinguishing these venues in a cultural landscape, especially from globally branded chain venues. 
Figure 5 - Interpretation of Naji Al Ali's 'Handala' cartoon, referring to the plight of Palestinian refugees (at the

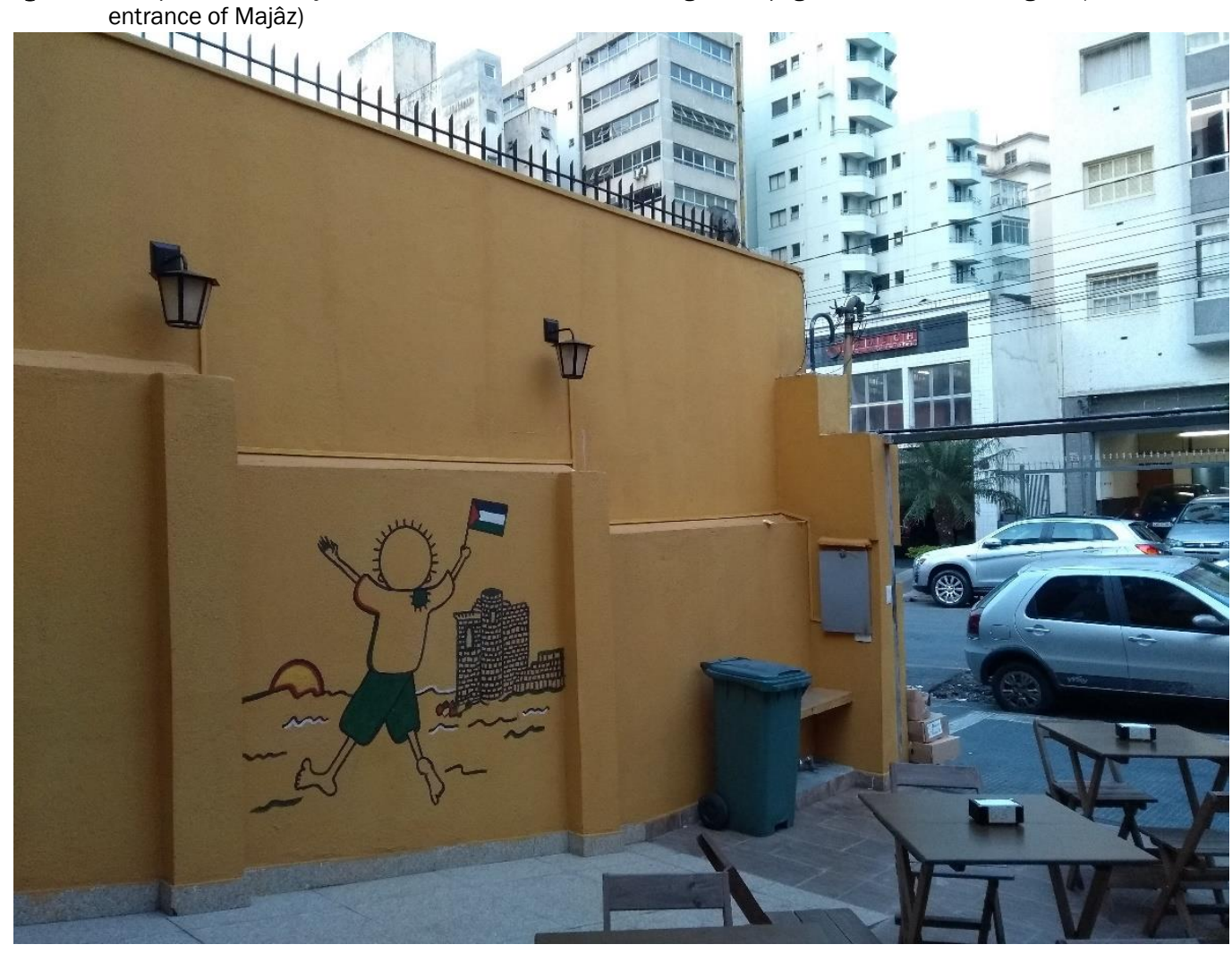

Figure 6 - Chef running pop-up restaurant at Fatiado Discos, with artwork in background

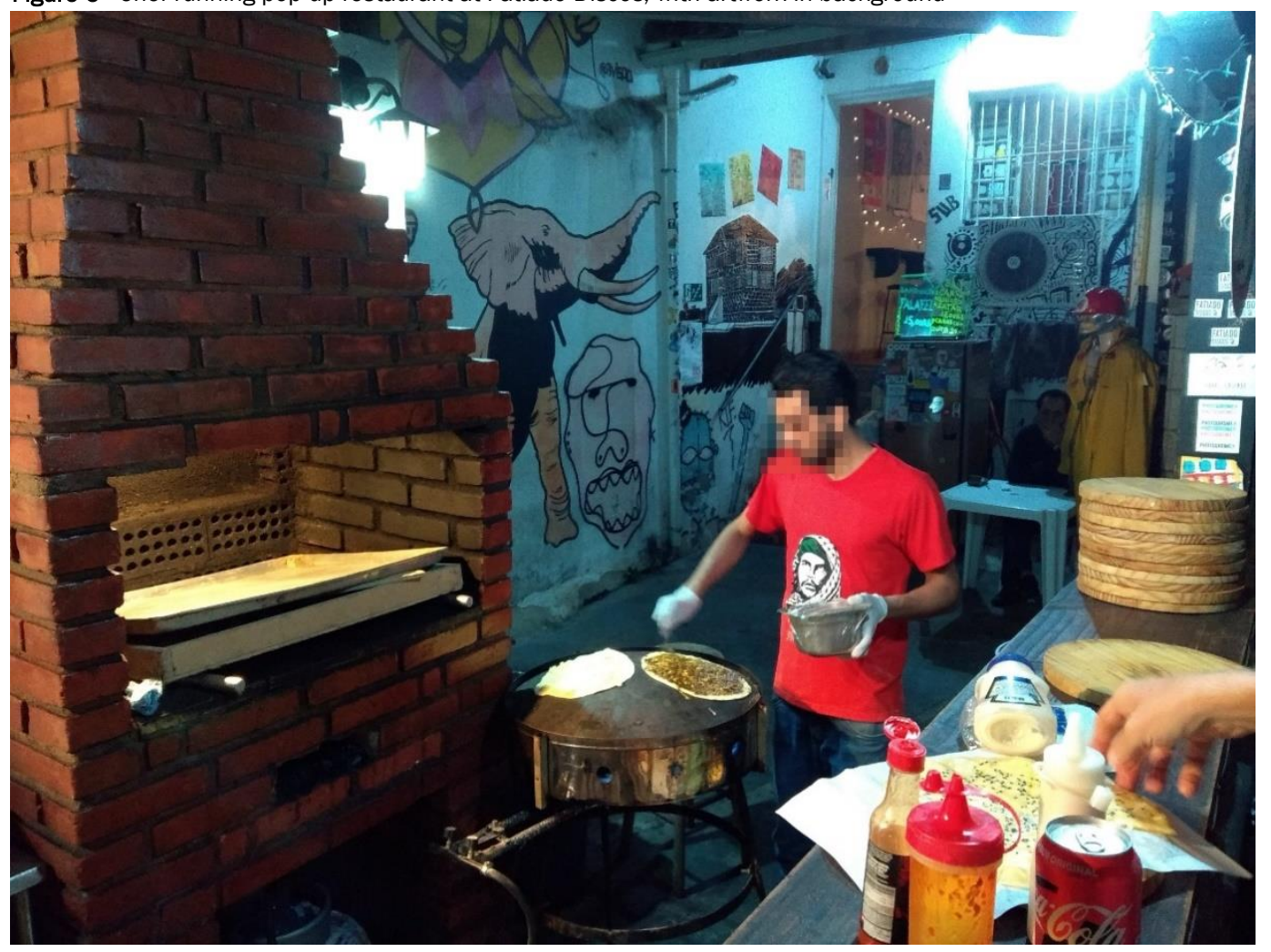




\subsection{Authentication of place-specific food experiences}

The novelties and quality of the food were significant aspects in the propositions for several of the restaurants and their operators. Importantly, foodstuffs invoked objective and subjective notions of authenticity (cf. Andriotis, 2009; Chhabra, 2012; Matos \& Barbosa, 2018; Wang, 1999). For example, Biyou'Z featured dishes from several countries including Senegal, Nigeria and Congo. The construction of the menu brought together dishes from numerous different countries under the broad label 'Africa'. In effect, the culinary and therefore cultural traditions of a diverse set of nations from across a whole continent were assembled and ordered in the (hybrid) experiential proposition. This construction of the 'African experience' was also reflected in the hiring policy: there was a preference to hire cooks and other staff from Africa, although not from a specific country. Staff with African origins were thus mobilised to authenticate the venue and the meals served there. Through these practices, the owner thus positioned a gastronomic visit to Biyou'Z as a touristic experience, displaying the continent for domestic and international audiences.

Recent debates concerning authenticity, of food and tourism, have shifted from defining authenticity and distinguishing between forms of authenticity to examining authentication: the processes by which qualities of authenticity are constructed, assigned, evaluated or experienced (cf. Chhabra, Lee, Zhao, \& Scott, 2013; Cohen \& Cohen, 2012; Lugosi, 2016; Mkono, 2013; Xie, 2011). Arguably, the selective ordering and display of foodstuffs, in a unique place, can be understood as the construction and therefore authentication of unique experiences, purposefully coupled with notions of otherness and thus migration. This was also where the personality of the owner and operator, as the embodiment of the 'experiential brand', came to the foreground. The personal explanations of dishes, ingredients, and their origins, coupled with the curated nature of the servicescape, were arguably psychological 'priming' strategies seeking to shape consumer perceptions and evaluations of the intrinsic qualities of the food consumption experience.

Congolinária's authentication strategies also placed the owner at the heart of its identity. Descriptions of the food and the venue in representations coupled these to the owner's origin and story, as migrant, to demonstrate the unique values entangled in the restaurant space and its experiential proposition. Significantly, this was tied to a wider set of value systems referencing vegan principles of the cooking, the quality of the ingredients and their crafted preparation. These positioned the food and hospitality practices of Congolinária in a middle class domain of class topography where providence and quality of ingredients, craft skills, and the authenticity and personality of the owner, which were explicitly narrated, became markers of differentiating cultural capital (Bourdieu, 1986; Warde, 2016).

The venues, its operators and their audiences thus had the capacity to become wider agents of urban transformation (cf. Lugosi et al., 2010). Mobilising economic, social and cultural capital in their consumption and mediation of food and hospitality experiences, positioned venues within broader practices of gentrification. Arguably, Majâz and Al Janiah exploited and fuelled gentrification processes in Santa Cecília and Bixiga, which were central neighbourhoods that had undergone significant transformation in recent years, with real estate development bringing new affluent groups, justifying the emergence of new entertainment, specialized retail services and hospitality businesses catering for these consumers (see Figure 7 for an overview of their spatial distribution in the urban landscape). This 'hipster invasion', particularly in Bixiga, may be attributed to the movement of habitués from another 'bohemian' area, Vila Madalena, who were 'sympathizers of the refugees', eager to 'consume an alternative culture' (Sampaio, 2018).

However, as also summarised in Figure 7, House of Food (the venue for Open Taste) and Fatiado Discos (which housed Congolinária) were based in relatively wealthy, upper middle-class areas of Pinheiros and Sumaré. In these cases, the venues may not have been driving gentrification, but they did arguably contribute to the touristification of city districts. The flourishing of these businesses in São Paulo expanded the supply side of the wider tourism sector. It is possible to argue that, at the time of writing, the majority of the clientele were composed of locals; however, their socio-spatial behaviour would ascribe them similar characteristics as tourists looking for novel, authentic experiences. Considering the diversity and complexity of contemporary mobilities, distinguishing between 'tourists' and 'locals' is unhelpful for understanding intersections between tourism and migration (cf. Allis, 2014; 2016). These venues created novel touristic experiences for domestic and international visitors alike. 
Figure 7 - The spatial distribution of the migrant owned/operated venues in São Paulo examined in this paper

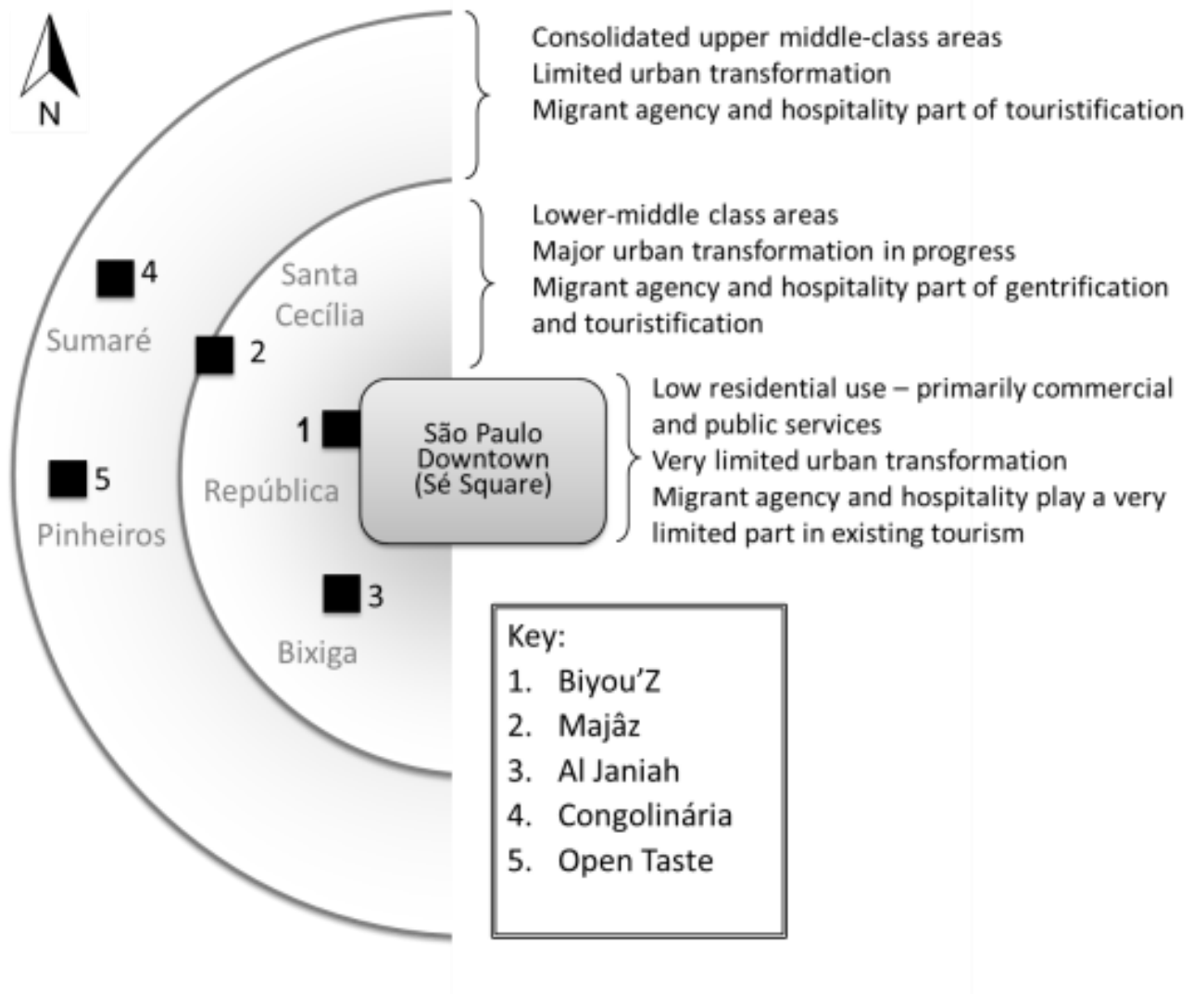

\subsection{Constructing hospitality venues as cultural spaces}

The construction, or perceived experience, of hospitable places is implicitly tied to the norms, values and interests of particular groups, which are mobilised and performed within those spaces through social practices (cf. Camargo, Cavenaghi, Pereira, \& Wada, 2018; Lugosi, Robinson, Golubovskaya, Foley, \& Harwell, 2016). Importantly, within this empirical study, the data highlighted how notions of difference were central to constructing communal values in the venues. The emphasis on authentic foods and cultural experiences, providence and the personal histories of 'foreign' entrepreneurs were part of business strategies to engage a wider range of publics in value creation. All these venues displayed 'otherness' as part of their experiential propositions. However, in many cases, otherness mobilised a broader set of social and political discourses. Representations of Congolinária, by its owner/operators, and other cultural commentators, foregrounded that the venture was tied to refugee experiences and solidarity. Within the servicescape, this was sometimes communicated through explicit signifiers, for example, signs referring to the 'Refugiados Bem-Vindos' [Refugees welcome] campaign. However, online representations of the venture and its owner highlighted the owner's activism and charitable work in support of homeless people and refugees (see e.g. Bastos, 2017). The valuation, and value, of the individual food(service) experience was thus amplified by the humanitarian connotations of its consumption.

Al Janiah and Majâz also sought to engage broader audiences by invoking wider socio-political discourses concerning displacement and migration in relation to Palestinian-Israeli relations. In both venues, there were numerous references to the Israel-Palestine conflict (see Figures 5 and 8). At Al Janiah, domestic political issues also emerged; for instance, it hosted a debate promoted by the campaign committee of a deputy candidate.

This was also highlighted in Fatiado Discos' hosting a pop-up restaurant run by two Palestinian refugees. Strategic coupling of (middle Eastern) foods and (refugee) chefs with global politics thus imbued the dining experience with new meanings, becoming an act of 'interpellation' or hailing (Althusser, 1971) as its operators called on customers to consume as an act of solidarity. This special event was promoted as 'Refugees' Tuesday', arguably to shed light on refugees' causes, whilst simultaneously mobilising emerging interests from diverse audiences for 'exotic' food. 


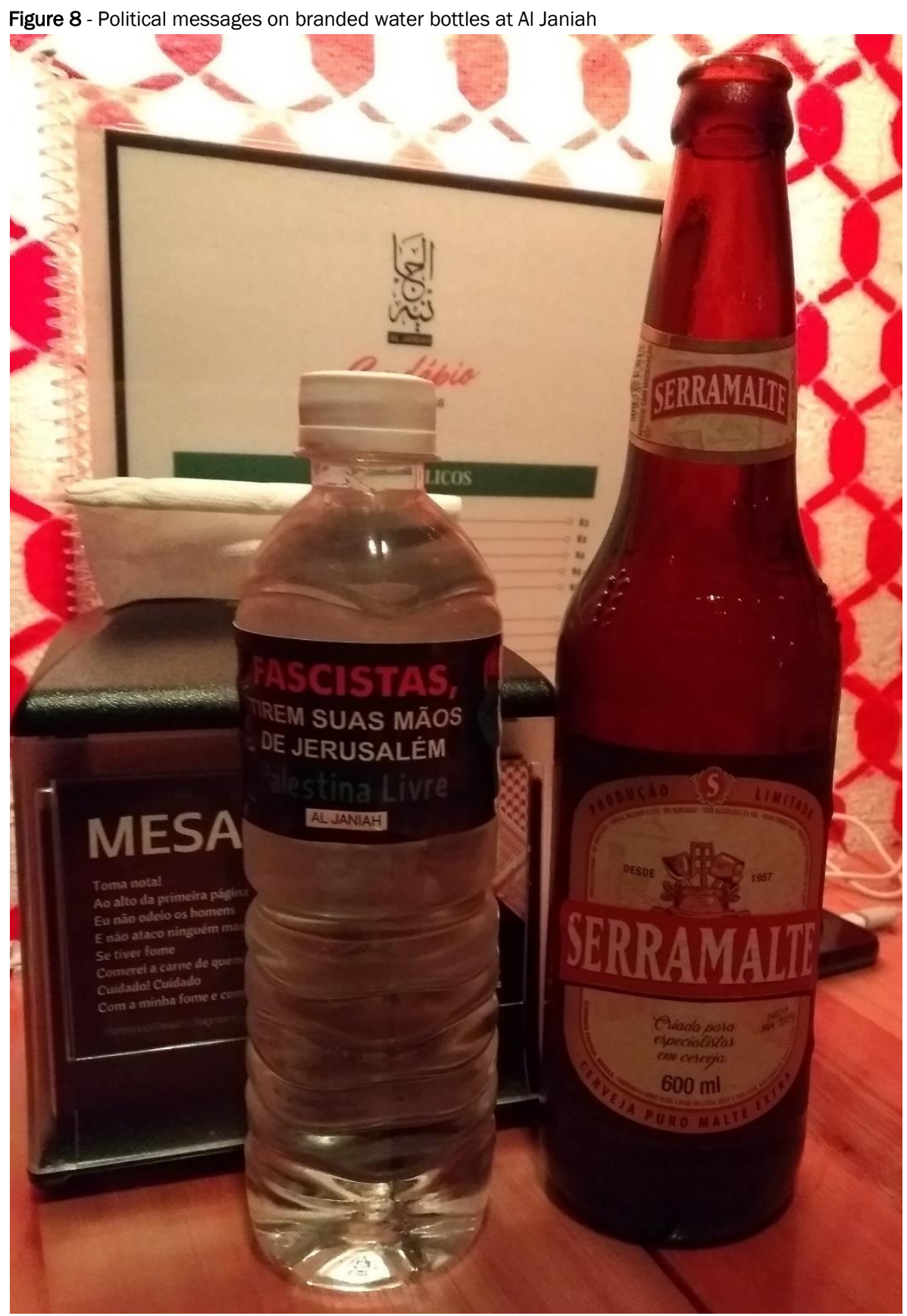

Moreover, hospitality venues acted as wider spaces for other groups and networks which either had a shared agenda or related political views, for example challenging existing societal power relations. Hosting events for 'left wing' activist groups, selling political literature, displaying explicit symbols of resistance and political activism thus engaged broader audiences (see Figures 9 and 10). Migrant and refugee identities were therefore mobilised as cultural and political resources.

Importantly these venues positioned themselves as more than simply foodservice providers - they operated as 'cultural centres', acting as focal points for multiple audiences and communities - including tourists (see also Figure 11 of the mobile bookstore outside Al Janiah). At Biyou'Z, for instance, visitors were invited to get 'to know a little of Africa' through gastronomy (Carvalho, 2017); Al Janiah was presented as 'more than a restaurant': it became a 'centre for refugees of many nationalities' (Vidal, 2017). Joanna (Open Taste) argued that their business aimed 'not only to showcase the food, but also the culture of the people' (McGill, 2018). As Terenzi (2016) observed, these new businesses helped to 'renew the already multicultural scene in São Paulo, bringing artistic and gastronomic novelties to this metropolis'.

Migrant entrepreneurs' practices reflected those identified in other international studies of hospitality (cf. Lugosi et al., 2010) and have a number of implications. Firstly, invoking these symbolic meanings supports 
differentiation in a (commercial and moral) marketplace. Secondly, coupling politics, social issues and leisure consumption helps to engage new audiences and representations of the venues by a more diverse range of cultural commentators, consumers and media organisations. Thirdly, constructing and positioning these venues as cultural centres for political consciousness raising and social action means they act as 'force multipliers' with the potential to amplify collective actions, and thus to facilitate wider social transformation.

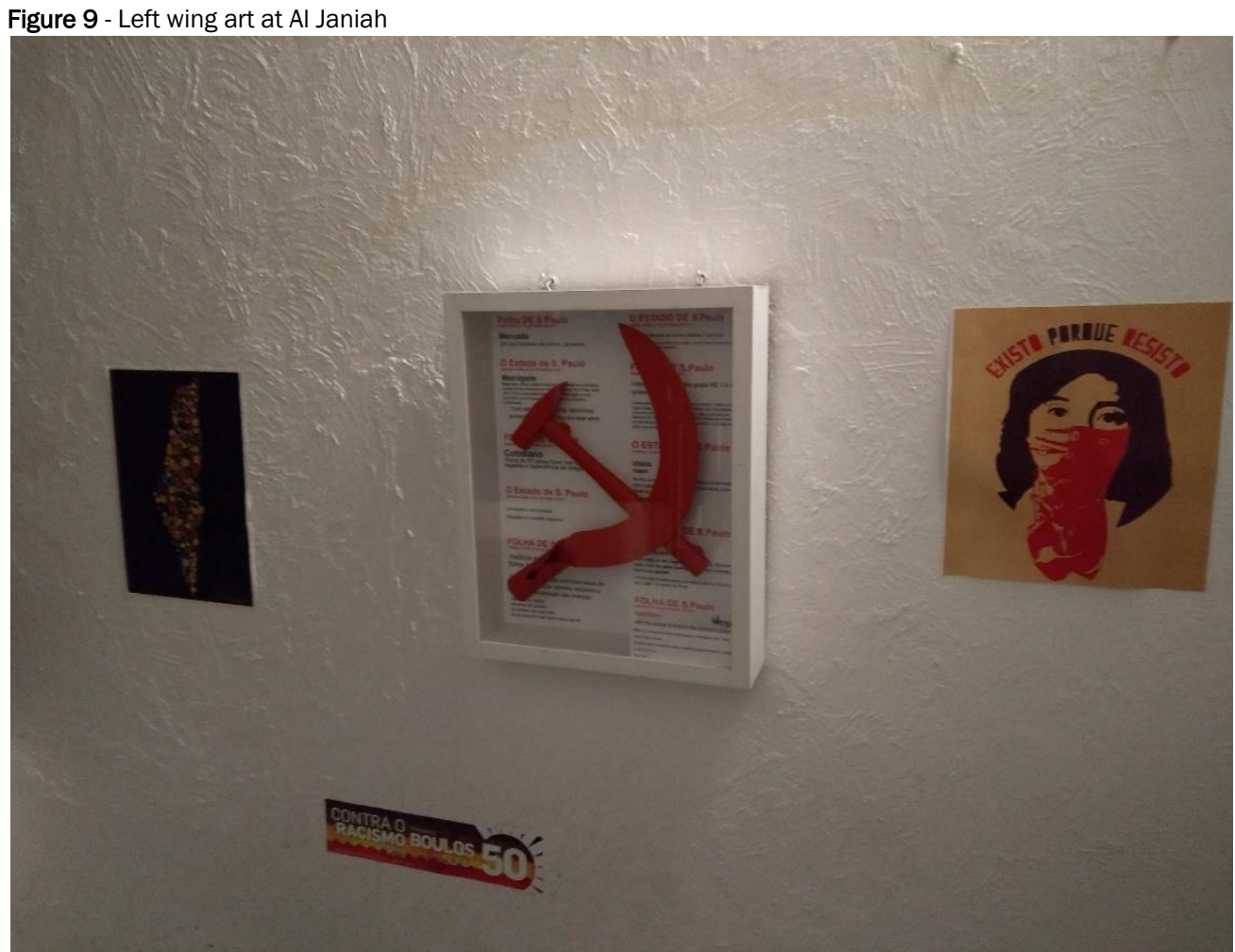

Figure 10 - Stall selling left wing literature at Al Janiah

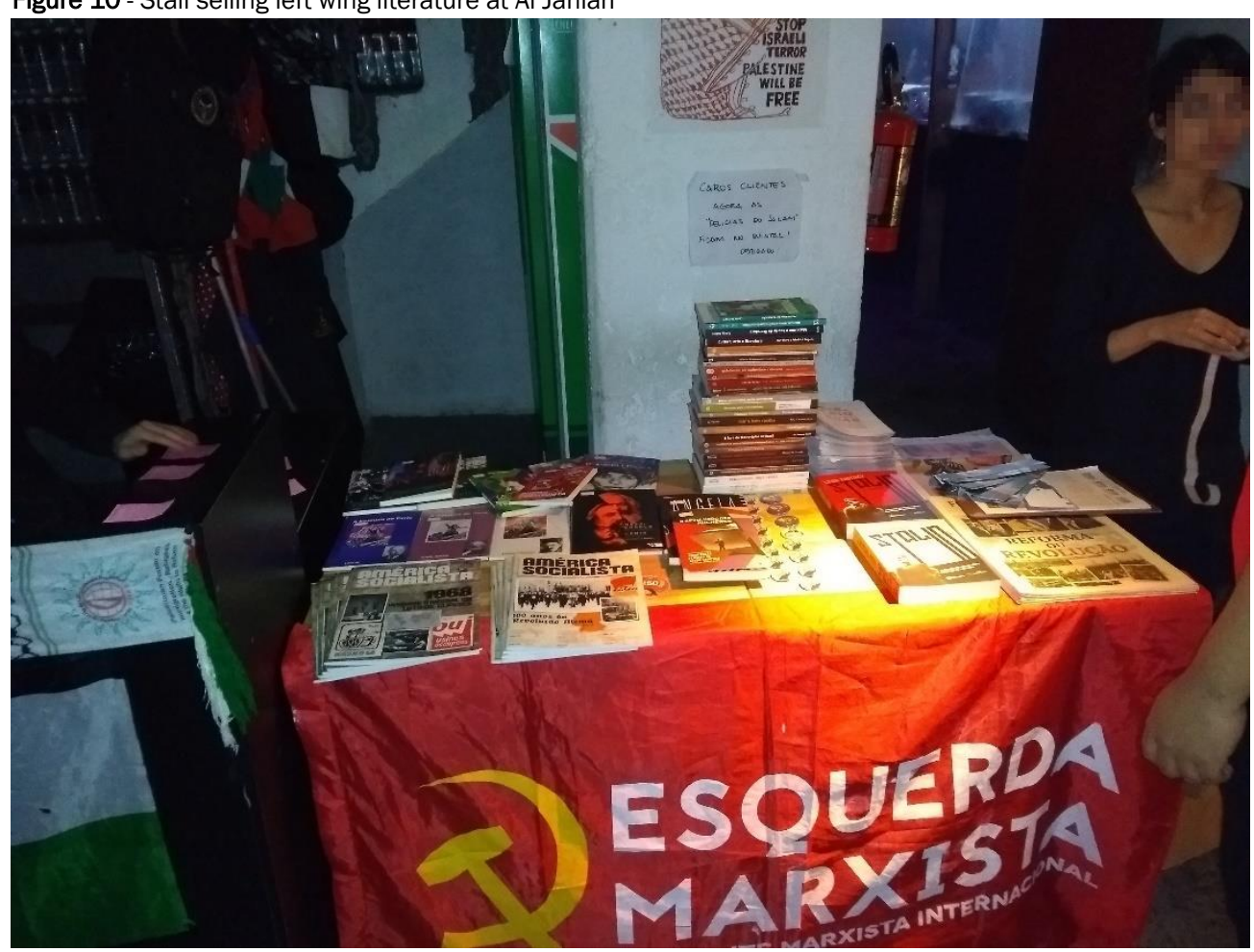




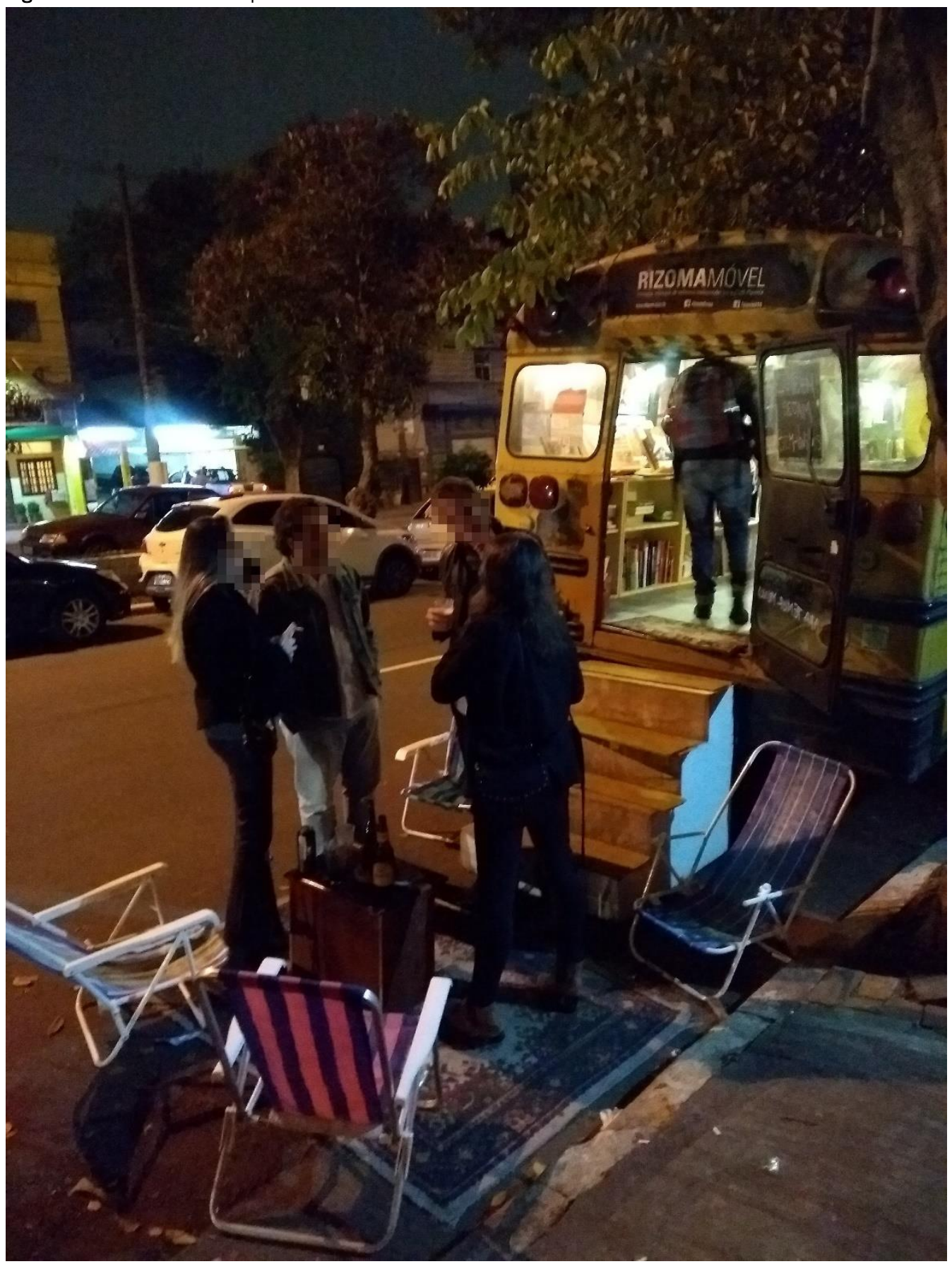

\subsection{Vitrine-ing}

A final area of practice evident in the venues and in the behaviours of their operators was the showcasing of refugee talent, which we tentatively refer to here as 'vitrine-ing'. This is distinct from the objectification of self, referred to earlier. Rather than foregrounding the personalities and histories of owners, the construction of vitrines refers to venues acting as curated entrepreneurial spaces where chefs' gastronomic capabilities were showcased. At the time of writing, Open Taste and its founder operated a pop-up restaurant, renting space in a mixed-use hospitality/retail/co-workspace venue once a week. Importantly, different (refugee) chefs cooked food during these short residencies. The open kitchen layout of the venue metaphorically acted as a 'vitrine', framing and channelling consumers' engagement with the refugees working in the kitchen (see Figure 12). Joanna facilitated the pop-up and promoted the events. The ambition was to expand this by operating a venue that was open on multiple days, hosting a diverse range of chefs. 
Reflecting the previous themes, the pop-up was used to singularise and qualify migrants' capacities, transforming their histories, identities and cooking abilities into 'valued goods', which were presented to consumers. As Scott (2012) and others have observed, entrepreneurs mobilised migrants' cultural capital to create use-value (i.e. chefs' cooking abilities produce flavoursome and attractive food). More importantly, foregrounding (migrant) identities, coupling them with the experiential propositions of consuming their foods at Open Taste, created leisure or touristic goods that had exchange value in a cultural marketplace (cf. Scott, 2012; Bourdieu, 1986). A consequence of vitrine-ing was that residencies in the pop-up space offered ways for refugees to expand their social capital, building relationships that translated into cooking work in other venues.

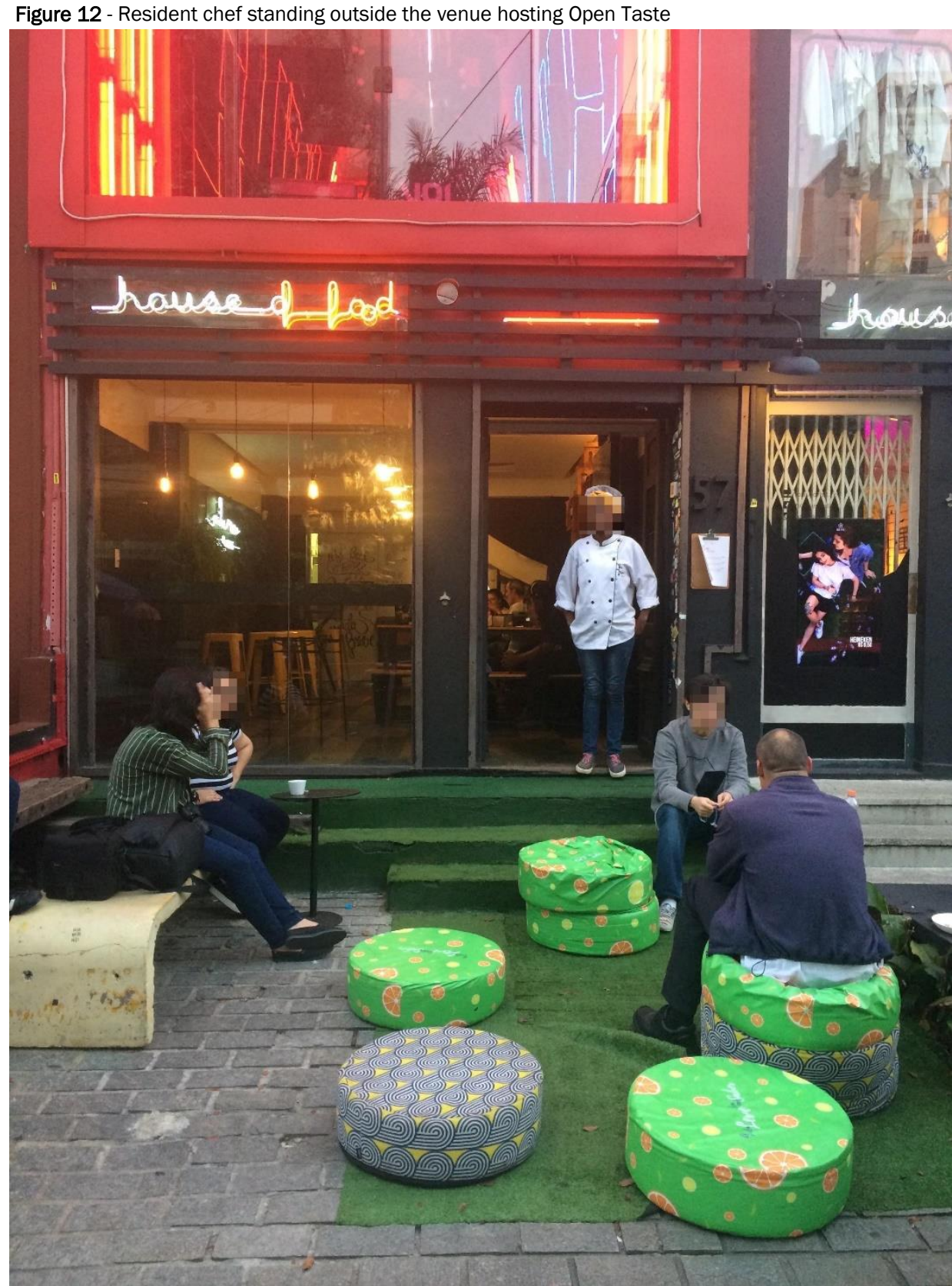

\section{CONCLUSION}

This paper has sought to explore the practices through which migrants seek to create value through operating hospitality venues within a wider urban tourism and leisure landscape. The discussion highlighted a number of strategies adopted to create distinctive experiential propositions. These included various representations, 
firstly of themselves as migrants, entrepreneurs and value creators; and secondly of their venues as places for showcasing 'foreign' cultural practices, values and knowledge through artwork, materiality and, importantly, food. It was argued that, within these practices, migrants strategically mobilised identities as resources to: a) create experiential propositions; b) couple those propositions to moral values concerning solidarity and resistance; and c) use propositions to engage a wide array of publics so the venues and the consumption experiences they offered extended beyond food and drink. Drawing on insights from valuation studies, the practices of these migrant entrepreneurs can be understood as purposeful attempts to singularize their unique 'goods', distinguishing them from others in the marketplace and attempting to qualify their distinct worth in a moral and commercial market space.

The issues identified through this exploratory analysis deserve further examination, using much greater depth of data, building on a wider sample of venues, migrant entrepreneurs, employees, consumers and external stakeholders, including cultural commentators. It would also be valuable to extend the focus of future studies to different national contexts, and cultural groups, whilst also considering the changing dynamics and impacts of valuation and value-creation practices over time.

It is common for migrant precincts to emerge as experiential leisure and tourist spaces, for instance, littleItalys, Greeces or Bangla-, China- and Korean-towns, all over the world (Shaw, 2011; Shaw, Bagwell, \& Karmowska, 2004). However, though this process has been observed in São Paulo for several decades (for example, Liberdade and Bixiga, respectively, as Asian and Italian gastronomic areas), the interactions between contemporary waves of migration, hospitality and tourism have yet to be discussed and analysed. The issues highlighted in this paper also open up further avenues for research, which have a range of implications. Specifically, from a critical perspective, the practices identified here represent the commodification of identity, or identities, which are deployed as assets. In the cases analysed here, these could be read as entrepreneurial attempts to create value for the benefit of migrants and refugees. However, there is a risk that migrant and refugee identities become decoupled from the people who originally experienced various forms of mobility including privileged and therefore elective, or conflict-driven and thus forced. The identities of migrant or refugee entrepreneurs and employees may become appropriated, cynically, to create and differentiate hospitality propositions, or leisure and tourism destinations more generally, transforming people into spectacles of consumption.

There are also inherent risks to tying economic and social wellbeing to a limited set of identity markers - i.e. 'migrant' or 'refugee'. This may shape the potential to adopt different acculturation strategies of integration or assimilation into a host society and the construction of alternative forms of identification. Further research can therefore examine, on a longitudinal basis, how notions of 'migrant' or 'refugee' are adopted, redefined or even abandoned by entrepreneurs over time as people settle in new places.

Alternative analyses of migrants' entrepreneurial valuation and value-creation practices evident in their hospitality and tourism ventures may focus on their transformational capacities. For example, these venues can facilitate labour market integration for other migrants and refugees. Furthermore, the valorisation of migrants and refugees, showcasing their capabilities and achievements through these entrepreneurial ventures, may also help to combat prejudice and negative representations of them. Future research can therefore examine the wider and longer terms impacts of these practices. Finally, research can also evaluate how these hospitality spaces interact with broader processes of urban transformation. Specifically, in establishing these venues as centres of value-based cultural activities, which attract educated and wealthy consumer segments, these venues may drive the expansion of the night-time leisure economy or urban regeneration. It is therefore fruitful to examine how migrants' entrepreneurial practices in creating distinctive hospitality and tourism venues impact on the characteristics of places and their existing residents.

\section{ACKNOWLEDGEMENT}

We are grateful to all the owners, operators, customers and other stakeholders who took time to speak to us during the study, and to the British Academy for funding this project through the Newton Fund (Grant reference: NMG2R2\100063). 


\section{REFERENCES}

Adler, P.A., \& Adler, P. (1987). Membership roles in field settings. Newbury Park, CA, Sage.

https://doi.org/10.4135/9781412984973

Adler, P.A., \& Adler, P. (1998). Observational techniques. In N. Denzin, \& Y. Lincoln, (Eds.), Collecting and interpreting qualitative materials (pp. 79-109). Newbury Park, CA: Sage.

Allis, T. (2014). Viajantes, visitantes, turistas... Em busca de conceitos em um mundo urbano, Caderno Virtual de Turismo, 14(1), 23-38.

(2016). Em busca das mobilidades turísticas. Plural, 23(2), 94-117.

https://doi.org/10.11606/issn.2176-8099.pcso.2016.125112

Allis, T. \& Lopez, M. P. (2018). Turismo post-conflicto: Desarrollo turístico local y estrategias para la integración social de refugiados. Revista Estudios y Perspectivas en Turismo, 27(4), 1003-1017.

Althusser, L. (1971). Lenin and philosophy and other essays. New York: Monthly Review Press.

Andriotis, K. (2009). Sacred site experience: A phenomenological study. Annals of Tourism Research, 36(1), 64-84. https://doi.org/10.1016/j.annals.2008.10.003

Baka, V. (2015). Understanding valuing devices in tourism through "place-making". Valuation Studies, 3(2), 149-180. https://doi.org/10.3384/VS.2001-5992.1532149

Bastos, E. (2017). Congolinária, gastronomia congolesa vegana por um refugiado. SPVEG Blog, post 08.09.2017. https://www.spveg.com/blog/congolinaria-gastronomia-congolesa-vegana-por-um-refugiado/ (Accessed 17.09.2018).

Baum, T., Kralj, A., Robinson, R. N., \& Solnet, D. J. (2016). Tourism workforce research: A review, taxonomy and agenda. Annals of Tourism Research, 60, 1-22. https://doi.org/10.1016/j.annals.2016.04.003

Berry, L.L., Wall, E.A., \& Carbone, L.P. (2006). Service clues and customer assessment of the service experience: Lessons from marketing. Academy of Management Perspectives, 20(2), $43-57$. https://doi.org/10.5465/amp.2006.20591004

Bourdieu, P. (1986). Distinction: A social critique of the judgement of taste. London: Routledge.

Secretaria Nacional de Justiça (2018). Refúgio em números. $3^{\text {rd }}$ Edition. Ministry of Justice. Available at: <http://www.acnur.org/portugues/wp-content/uploads/2018/04/refugio-em-numeros_1104.pdf> (Acessed: 2709 2018).

Brown, S., \& Patterson, A. (2000). Knick-knack paddy-whack, give a pub a theme. Journal of Marketing Management, 16(6), 647-662. https://doi.org/10.1362/026725700785045903

Büscher, M., \& Urry, J. (2009). Mobile methods and the empirical. European Journal of Social Theory, 12(1), p. 99-116. https://doi.org/10.1177/1368431008099642

Callon, M. (1998). An essay on framing and overflowing: Economic externalities revisited by sociology. The Sociological Review, 46(S1), 244-269. https://doi.org/10.1111/j.1467-954X.1998.tb03477.x

Callon, M. (2007). An essay on the growing contribution of economic markets to the proliferation of the social. Theory, Culture \& Society, 24(7-8), 139-163. https://doi.org/10.1177/0263276407084701

Callon, M., \& Muniesa, F. (2005). Economic markets as calculative collective devices. Organization Studies, 26(8), 1229-1250. https://doi.org/10.1177/0170840605056393

Callon, M., Méadel, C., \& Rabeharisoa, V. (2002). The economy of qualities. Economy \& Society, 31(2), 194217. https://doi.org/10.1080/03085140220123126

Camargo, L. O., Cavenaghi, A. J., Pereira, D. C., \& Wada, E. K. (2018). Fans of Sesc in São Paulo: a study on hospitality and welcome. Revista Brasileira de Pesquisa em Turismo, 12(2), $46-64$. https://doi.org/10.7784/rbtur.v12i2.1403 
Carvalho, J. (2017). Conheça a África com os deliciosos pratos do Biyou'Z. Sobrereviva em São Paulo, post 06.02.2017. https://www.sobrevivaemsaopaulo.com.br/2017/02/06/conheca-mais-da-africa-com-os-deliciosos-pratos-do-biyouz/. (Accessed 08.10.2018).

Chhabra, D. (2012). Authenticity of the objectively authentic. Annals of Tourism Research, 39(1), 499-502. https://doi.org/10.1016/i.annals.2011.09.005

Chhabra, D., Lee, W., Zhao, S., \& Scott, K. (2013). Marketing of ethnic food experiences: Authentication analysis of Indian cuisine abroad. Journal of Heritage Tourism, 8(2-3), 145-157. https://doi.org/10.1080/1743873X.2013.767816

Cochoy, F. (2004). Is the modern consumer a Buridan's donkey? Product packaging and consumer choice. In K. Ekström, \& H. Brembeck (Eds.), Elusive consumption (pp. 205-227). Oxford: Berg.

Cochoy, F. (2008). Calculation, qualculation, calqulation: Shopping cart arithmetic, equipped cognition and the clustered consumer. Marketing Theory, 8(1), 15-44. https://doi.org/10.1177/1470593107086483

Cohen, E., \& Cohen, S. A. (2012). Authentication: Hot and cool. Annals of Tourism Research, 39(3), 12951314. https://doi.org/10.1016/i.annals.2012.03.004

Cohen, S. A. Duncan, T. \& Thulenmark, M. (2015). Lifestyle mobilities: The crossroads of travel, leisure and migration. Mobilities, 10(1), 155-172. https://doi.org/10.1080/17450101.2013.826481

Creswell, T. (2010). Towards a politics of mobility. Environment \& Planning D: Society \& Space, 28, 17-31. https://doi.org/10.1068/d11407

Davis, C. S., \& Breede, D. (2015). Holistic ethnography: Embodiment, emotion, contemplation, and dialogue in ethnographic fieldwork. Journal of Contemplative Inquiry, 1, 77-99.

Duncan, T., Scott, D. G., \& Baum, T. (2013). The mobilities of hospitality work: An exploration of issues and debates. Annals of Tourism Research, 41, 1-19. https://doi.org/10.1016/i.annals.2012.10.004

Dwyer, L., Seetaram, N., Forsyth, P., \& King, B. (2014). Is the migration-tourism relationship only about VFR? Annals of Tourism Research, 46, 130-143 https://doi.org/10.1016/i.annals.2014.03.009

Germann Molz, J., \& Gibson, S. (2007). Mobilizing hospitality: The ethics of social relations in a mobile world. Aldershot: Ashgate.

Hall C.M., \& Williams A.M. (eds) (2002) Tourism and migration. Dordrecht: Springer. https://doi.org/10.1007/978-94-017-3554-4

Hansen, S. (2008). Society of the appetite: Celebrity chefs deliver consumers. Food, Culture \& Society, 11(1), 49-67. https://doi.org/10.2752/155280108X276050

Hoffman, K., \& Turley, L. (2002). Atmospherics, service encounters and consumer decision making: An integrative perspective. Journal of Marketing Theory \& Practice, 10(3), 33-47. https://doi.org/10.1080/10696679.2002.11501918

IBGE (2000). Brasil: 500 anos de povoamento. Rio de Janeiro: IBGE.

Ivanov S., \& Stavrinoudis, T. A. (2018). Impacts of the refugee crisis on the hotel industry: Evidence from four Greek islands. Tourism Management, 67, 214-223 https://doi.org/10.1016/j.tourman.2018.02.004

Janta, H., Cohen, S. A., \& Williams, A. M. (2015). Rethinking visiting friends and relatives mobilities. Population, Space \& Place, 21(7), 585-598. https://doi.org/10.1002/psp.1914

Jones, M. T. (2009). A celebrity chef goes global: The business of eating. Journal of Business Strategy, 30(5), 14-23. https://doi.org/10.1108/02756660910987572

Joppe, M. (2012). Migrant workers: Challenges and opportunities in addressing tourism labour shortages. Tourism Management, 33(3), 662-671. https://doi.org/10.1016/j.tourman.2011.07.009

Lincoln, Y., \& Guba, E. (2013). The constructivist credo. Walnut Creek, CA: Left Coast Press. 
Lugosi, P. (2016). Socio-technological authentication. Annals of Tourism Research, 58, $100-113$. https://doi.org/10.1016/j.annals.2016.02.015

Lugosi, P., Bell, D., \& Lugosi, K. (2010). Hospitality, culture and regeneration: Urban decay, entrepreneurship and the 'ruin' bars of Budapest. Urban Studies, 47(14), 3079-3101. https://doi.org/10.1177/0042098009360236

Lugosi, P., Janta, H., \& Watson, P. (2012). Investigative management and consumer research on the internet. International Journal of Contemporary Hospitality Management, 24(6), 838-854. https://doi.org/10.1108/09596111211247191

Lugosi, P., Robinson, R.N., Golubovskaya, M., Foley, L., \& Harwell, J. (2016). Experiencing parenthood, care and spaces of hospitality. The Sociological Review, 64(2), 274-293. https://doi.org/10.1111/1467954X.12330

Lury, C. (2012). 'Bringing the world into the world': The material semiotics of contemporary culture. Distinktion: Scandinavian Journal of Social Theory, $13(3), 267-260$. https://doi.org/10.1080/1600910X.2012.728144

McGill, D. (2018). Em São Paulo, start-up de refugiada síria cria oportunidades de negócios para outros refugiados. ACNUR Brasil. http://www.acnur.org/portugues/2018/05/30/em-sao-paulo-start-up-de-refugiada-siria-cria-oportunidades-de-negocios-para-outros-refugiados/. (Accessed 01.10.2018).

Marwick, A. E. (2013). Status update: Celebrity, publicity and branding in the social media age. New Haven: Yale University Press.

Marwick, A. E. (2015). Instafame: Luxury selfies in the attention economy. Public Culture, 27(1 75), 137-160. https://doi.org/10.1215/08992363-2798379

Marwick, A. E., \& Boyd, D. (2011). I tweet honestly, I tweet passionately: Twitter users, context collapse, and the imagined audience. New Media \& Society, 13(1), 114-133. https://doi.org/10.1177/1461444810365313

Matos, M.B., \& Barbosa, M. (2018). Authenticity in tourism experiences: A new approach based on Edgar Morin's Complexity Theory. Revista Brasileira de Pesquisa em Turismo, 12(3), $154-171$. https://doi.org/10.7784/rbtur.v12i3.1457

Mena, I. (2014). Conheça o House of Food: Um espaço de coworking só para quem conzinha profissionalmente. Projeto Draft, post 11.11.2014. https://projetodraft.com/a-house-of-food-inova-o-ja-efervescentecenario-dos-coworking-spaces-este-e-para-cozinheiros/. (Accessed 10.10.2018).

Meyer, D. (2006). Setting the table: The transforming power of hospitality in business. New York: HarperCollins.

Mkono, M. (2013). Hot and cool authentication: A netnographic illustration. Annals of Tourism Research, 41 , 215-218. https://doi.org/10.1016/j.annals.2013.01.014

O'Reilly, K. (2003) When is a tourist? The articulation of tourism and migration in Spain's Costa del Sol. Tourist Studies, 3 (3), 301-317. https://doi.org/10.1177/1468797603049661

Papacharissi, Z. (2012). Without you, I'm nothing: Performances of the self on Twitter. International Journal of Communication, 6, 18, 1989-2006.

Patton, M.Q. (2015). Qualitative research and evaluation methods (4th ed.). London: Sage.

Purnell, D., \& Breede, D. C. (2018). Traveling the third place: Conferences as third places. Space \& Culture, 21(4), 512-523. https://doi.org/10.1177/1206331217741078

Ren, C., \& Mahadevan, R. (2018). "Bring the numbers and stories together": Valuing events. Annals of Tourism Research, 72, 75-84. https://doi.org/10.1016/j.annals.2018.06.008

Ren, C., Petersen, M. K., \& Dredge, D. (2015). Guest editorial: Valuing tourism. Valuation Studies, 3(2), 8596. https://doi.org/10.3384/VS.2001-5992.153285 
Sampaio, P. (2017). Bar de refugiados, discos de vinil e papo cabeça: Bixiga é o novo point hipster de SP. Blog do Paulo Sampaio, post 04.04.2017. https://paulosampaio.blogosfera.uol.com.br/2017/04/04/barde-refugiados-discos-de-vinil-e-papo-cabeca-bixiga-e-o-novo-point-hipster-de-sp/. (Accessed 08.10.2018).

Senha, R. (2014). Depois dos peruanos, restaurantes populares africanos ganham espaço no centro de SP. Folha se São Paulo, 12 January 2014. https://www1.folha.uol.com.br/saopaulo/2014/01/1395740-depois-dos-peruanos-restaurantes-populares-africanos-ganham-espaco-no-centro-de-sp-shtml (Accessed 09.10.18)

Scott, M. (2012). Cultural entrepreneurs, cultural entrepreneurship: Music producers mobilising and converting Bourdieu's alternative capitals. Poetics, 40(3), 237-255. https://doi.org/10.1016/j.poetic.2012.03.002

Shaw, S. J. (2011). Marketing ethnoscapes as spaces of consumption: 'Banglatown-London's Curry Capital'. Journal of Town \& City Management, 1(4), 381-395.

Shaw, S., Bagwell, S., \& Karmowska, J. (2004). Ethnoscapes as spectacle: Reimaging multicultural districts as new destinations for leisure and tourism consumption. Urban Studies, 41(10), 1983-2000. https://doi.org/10.1080/0042098042000256341

Smith, M. K., Egedy, T., Csizmady, A., Jancsik, A., Olt, G., \& Michalkó, G. (2018). Non-planning and tourism consumption in Budapest's inner city. Tourism Geographies, 20(3), 524-548. https://doi.org/10.1080/14616688.2017.1387809

Svejenova, S., Mazza, C., \& Planellas, M. (2007). Cooking up change in haute cuisine: Ferran Adrià as an institutional entrepreneur. Journal of Organizational Behavior, 28(5), 539-561. https://doi.org/10.1002/job.461

Terenzi, G. (2016). Imigrantes trazem novidades gastronômicas e culturais a São Paulo. Folha de São Paulo, post 06.11.2016. https://www1.folha.uol.com.br/saopaulo/2016/11/1829396-imigrantes-trazem-novidades-gastronomicas-e-culturais-a-sao-paulo-veja-guia.shtml. (Accessed 01.10.2018).

Torres, E. N., Lugosi, P., Orlowski, M., \& Ronzoni, G. (2018). Consumer-led experience customization: A sociospatial approach. Journal of Service Management, 29(2), 206-229. https://doi.org/10.1108/JOSM-06$\underline{2017-0135}$

Urry, J. (2007). Mobilities. Cambridge: Polity Press.

UNHCR Brasil (2018). Dados sobre o refúgio no Brasil. http://www.acnur.org/portugues/dados-sobre-refugio/dados-sobre-refugio-no-brasil/. (Accessed 06.10.2018).

Vidal, H. (2017). No Bixiga, o Al Janiah é mais do que um restaurante comandado por refugiados palestinos, São Paulo São, post 03.05.2017. https://saopaulosao.com.br/nossas-pessoas/1279-no-bixiga-o-al-janiahe-mais-do-que-um-restaurante-comandado-por-refugiados-palestinos.html. (Accessed 03.10.2018).

Wang, N. (1999). Rethinking authenticity in tourism experience. Annals of Tourism Research, 26(2), 349370. https://doi.org/10.1016/S0160-7383(98)00103-0

Warde, A. (2016). The practice of eating. Cambridge: Polity Press. https://doi.org/10.1080/09503153.2015.1087492

Williams, A. M., King, R., Warnes, A., \& Patterson, G. (2000). Tourism and international retirement migration: new forms of an old relationship in southern Europe. Tourism Geographies, 2(1), 28-49. https://doi.org/10.1080/146166800363439

World Bank (2018). International tourism, number of arrivals. https://data.worldbank.org/indicator/ST.INT.ARVL?view=map. (Accessed 06.10.2018).

Xie, P. F. (2011). Authenticating ethnic tourism. Bristol: Channel View Publications. 


\section{Informations on the authors}

\section{Peter Lugosi}

Reader at the Oxford School of Hospitality Management, Oxford Brookes University, United Kingdom. Peter has researched and published on a wide range of subjects including customer experiences, migration and migrant labour issues, parenting cultures, research methods, and organisational behaviour. Peter co-founded the Hospitality \& Society journal, and he is currently the Controversies and Reviews Editor. He serves on a number of journal editorial boards including the International Journal of Contemporary Hospitality Management, Journal of Business Research, International Journal of Tourism Research, Journal of Destination Marketing and Management, and Annals of Leisure Research.

Contribution: Participated in all stages of the project including conceptualising the study and its objectives, reviewing the literature, and collecting and analysing the data.

E-mail: plugosi@brookes.ac.uk

ORCID: https://orcid.org 0000-0002-7611-128X

\section{Thiago Allis}

Assistant professor at School of Arts, Sciences and Humanities (EACH), at University of São Paulo, Brazil. His scholarly and research interests include urban tourism, regional and urban planning, and tourism mobilities. Thiago has lead and participated in several research and outreach projects funded by Brazilian and international agencies, with tourism, urban planning, mobilities and migration as subjects. After a stay in East Timor as an invited lecturer in 2012, Thiago started to combine tourism and (post-)conflict in his academic activities.

Contribution: Participated in all stages of the project including conceptualising the study and its objectives, reviewing the literature, and collecting and analysing the data.

E-mail: thiagoallis@usp.br

ORCID: http://orcid.org/0000-0002-9070-7928 


\section{APPENDIX: VENUE/OPERATOR VIGNETTES}

Al Janiah is an Arab restaurant, which first opened in central São Paulo (Anhangabaú) in 2016. Owned by a Brazilian-Palestinian and other refugees, it became an arena for political debate, focusing on denouncing the occupation of Palestine, and aligned with left-wing movements in Brazil. In a short time, fuelled by press and social network promotion, demand grew and the business moved to a larger venue, in the neighbourhood of Bixiga, a traditionally Italian gastronomic area. According to their website, Al Janiah was a "political and cultural space [...] where politics, art, culture, music and cinema express themselves critically through events, courses, theatre, book launches, film shows and photo exhibitions.' Their aim was to 'broaden the public's [...] engagement with culture, politics and issues at stake in the country and in the world [...] creating a platform for uniting struggles for political transformation'.

Biyou'Z was created as a response to the lack of spaces offering African gastronomy in São Paulo, despite the substantial presence of African migrants in the city, mainly in the República and Santa Ifigênia districts. The owner first arrived in Brazil in Brasília, as a guest of a family diplomat; so her background and mobility was different from refugees. Despite its Cameroonese roots, the restaurant described itself on its website as aiming to provide a 'great range of African [cuisines] from various regions of that continent', displaying recipes and artistic elements from several countries including Angola, Nigeria, Senegal, Ghana and Cameroon. Biyou'Z regularly featured in the gastronomic sections of local newspapers.

Congolinária was initially a pop-up restaurant or on-demand catering service, which began a partnership in 2017 with Fatiado Discos, a two-storey bar in the middle-class Sumare district. The owner, Pitchou Luambo, is a Congolese refugee and its market positioning was based on vegan food. As with many refugees, Pitchou was not allowed to practice his profession, law, in Brazil, so food and cultural entrepreneurship became an economic substitute. The business promoted African culture through food, in addition to aligning with animal rights principles. Before engaging in gastronomic services, Pitchou founded GRIST (the Homeless Migrants and Refugees Group).

Majâz - in Arabic, 'crossing' - was inaugurated in mid-2018, by a group of refugees with experience of another refugee-led restaurant (Al Janiah). With a more subtle appeal to political issues (relating to Palestine and Brazilian national agendas), the venue was dedicated to 'Palestinian gastronomy, made with traditional Arabic ingredients'. The restaurant was located in the heart of Santa Cecilia, a central district of São Paulo, which recently emerged as a cultural and gastronomic leisure and tourist destination in the city.

Open Taste was the one of Joanna Ibrahim's initiatives at Bab Sharki, a start-up that became 'a shared business platform with other refugees living in São Paulo to enable the sale of products and services, generate visibility for their enterprises and create opportunities for a new life with dignity' (McGill, 2018). At the time of writing, Open Taste operated a pop-up residency at the House of Food, with different refugees cooking food during each event. Open Taste helped to facilitate these residencies and promoted the gastronomic events through social media. The plan was to expand this and to occupy a venue permanently, offering residencies to chefs more frequently. 